\title{
Nutrient regulation of insulin secretion and action
}

\section{Philip Newsholme, Vinicius Cruzat, Frank Arfuso and Kevin Keane}

School of Biomedical Sciences, CHIRI Biosciences Research Precinct, Curtin University, GPO Box U1987, Perth, Western Australia, Australia
Correspondence should be addressed to P Newsholme Email

philip.newsholme@

curtin.edu.au

\begin{abstract}
Pancreatic $\beta$-cell function is of critical importance in the regulation of fuel homoeostasis, and metabolic dysregulation is a hallmark of diabetes mellitus (DM). The $\beta$-cell is an intricately designed cell type that couples metabolism of dietary sources of carbohydrates, amino acids and lipids to insulin secretory mechanisms, such that insulin release occurs at appropriate times to ensure efficient nutrient uptake and storage by target tissues. However, chronic exposure to high nutrient concentrations results in altered metabolism that impacts negatively on insulin exocytosis, insulin action and may ultimately lead to development of DM. Reduced action of insulin in target tissues is associated with impairment of insulin signalling and contributes to insulin resistance (IR), a condition often associated with obesity and a major risk factor for DM. The altered metabolism of nutrients by insulin-sensitive target tissues (muscle, adipose tissue and liver) can result in high circulating levels of glucose and various lipids, which further impact on pancreatic $\beta$-cell function, IR and progression of the metabolic syndrome. Here, we have considered the role played by the major nutrient groups, carbohydrates, amino acids and lipids, in mediating $\beta$-cell insulin secretion, while also exploring the interplay between amino acids and insulin action in muscle. We also focus on the effects of altered lipid metabolism in adipose tissue and liver resulting from activation of inflammatory processes commonly observed in DM pathophysiology. The aim of this review is to describe commonalities and differences in metabolism related to insulin secretion and action, pertinent to the development of DM.
\end{abstract}

\author{
Key Words \\ - diabetes \\ - insulin \\ - insulin resistance \\ - nutrients \\ - metabolism \\ - inflammation
}

\section{Introduction}

Homoeostatic regulation of fuel metabolism in the body is a tightly controlled process and dysregulation can lead to pathological conditions such as diabetes mellitus (DM), cardiovascular disease, stroke, renal disease and other manifestations of the metabolic syndrome. Glucose, the body's primary metabolic fuel source, is ingested usually in polymeric form following the consumption of a mixed meal, and the subsequent postprandial elevation in blood glucose level is stringently modulated by the release of the pancreatic hormones insulin and glucagon. These hormones target metabolically active tissues such as muscle, adipose tissue and liver in order to maintain blood glucose concentration within narrow limits ( 4.0-6.0 mmol/1). However, dysregulation of metabolic processes may result in chronic hyperglycaemic, dyslipidaemic or glucolipotoxic conditions that may negatively impact a wide variety of tissues and organs including pancreatic islets, skeletal muscle, adipose tissue and the liver and are frequently observed in DM.

According to the International Diabetes Federation (IDF), in 2011, 336 million of the world's population

Published by Bioscientifica Ltd 
( $6.4 \%)$ had either type 1 (T1DM) or type $2 \mathrm{DM}$ (T2DM), yet the prevalence is continuing to rise at rapid rates and is projected to exceed 550 million by 2030 (Whiting et al. 2011). Furthermore, T2DM is by far the most common form of the disease, representing about $90-95 \%$ of DM cases. Pancreatic islets are specialised and highly vascularised structures that monitor the nutrient contents of the blood stream and consist of mainly five cell types; $\alpha$-cells, $\beta$-cells, $\delta$-cells, ghrelin cells ( $\gamma$-cells) and pancreatic peptide (PP)-secreting cells (Wierup et al. 2014). Islets continually sample blood from the branches of the splenic and pancreaticoduodenal arteries (Gray's Anatomy 1995) and react to elevated dietary nutrients by directly secreting insulin from $\beta$-cells into the blood stream or glucagon from $\alpha$-cells (in response to nutrient-deprived states such as fasting and starvation). Interestingly, $\beta$-cells are the most studied cell of the islet and account for $\sim 50 \%$ of the islet cell mass in humans, while $\alpha$-cells comprise about $35-40 \%$, with the remainder made up of somatostatinsecreting $\delta$-cells, $\gamma$-cells and PP-cells that play a regulatory function (Cabrera et al. 2006, Newsholme et al. 2011, Rorsman \& Braun 2013, Wierup et al. 2014). As $\beta$-cells are responsible for the biosynthesis and distribution of insulin into the blood stream, they have an important clinical impact. Diminished glucose-stimulated insulin secretion (GSIS) and $\beta$-cell failure correlate with DM development (Jensen et al. 2008, Newsholme \& Krause 2012), and consequently it is important to determine the metabolic stimulus-secretion coupling factors that influence $\beta$-cell insulin production and release, with a view to develop novel therapeutic strategies.

However, the progression of DM does not solely rest with $\beta$-cell dysfunction, as IR is a major contributor and a condition normally associated with obesity. Importantly, downstream of $\beta$-cell insulin production/release, receptor binding and insulin signalling in target tissues and organs are essential for metabolic responses. Failure to respond adequately to insulin, following ligation of its receptor in target tissues, results in excess blood glucose. This is a key determinant in the development of T2DM and ultimately overwhelms the capacity of pancreatic $\beta$-cells to produce sufficient insulin, contributing to excessive blood glucose. The present review explores the metabolic factors that regulate insulin biosynthesis and release from pancreatic $\beta$-cells and also describes the metabolic consequence of attenuated insulin action in target tissues. This review unites the metabolic facets of insulin secretion and action that are pertinent to the development of DM.

\section{Metabolic regulation of $\beta$-cell insulin secretion}

\section{Biochemical mechanisms of insulin secretion}

Insulin exocytosis is a highly controlled process, and many factors actively promote insulin release (refer to $\mathrm{Fu}$ et al. (2013) for more detail). As carbohydrates are normally the primary source of fuel in food and glucose is the primary insulin secretagogue (see Flatt \& Lenzen (1994) and Fu et al. (2013)), traditional models of insulin exocytosis are based on an increase in the $\beta$-cell intracellular ATP:ADP ratio, following elevated glucose metabolism. Enhanced flux through the glycolytic pathway and tricarboxylic acid cycle (TCA) results in elevated mitochondrial ATP generation, following substrate-level phosphorylation and electron transport in the mitochondria utilising the electron donors NADH and $\mathrm{FADH}_{2}$. The enhanced ATP:ADP ratio induces plasma membrane depolarisation

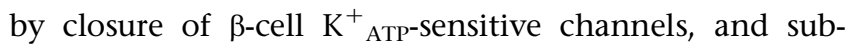
sequently the opening of voltage-gated calcium channels (Fig. 1; Jensen et al. 2008, Newsholme \& Krause 2012). The resultant influx of $\mathrm{Ca}^{2+}$ leads to insulin export through fusion of a readily releasable pool of insulin-containing vesicles with the plasma membrane (Komatsu et al. 2013). This triggering mechanism of $\mathrm{K}_{\mathrm{ATP}}$-dependent GSIS is responsible for the first phase of the insulin secretory response, over 5-10 $\mathrm{min}$, but the second, more sustained phase of insulin release over a period of $30-60 \mathrm{~min}$ is absolutely dependent on metabolic stimulus-secretion coupling and was first described in rat and mouse $\beta$-cells in 1992 (Fig. 2). Experimentally, when $\mathrm{K}^{+}{ }_{\text {ATP-sensitive }}$ channels were prevented from closing by addition of diazoxide (Gembal et al. 1992, Sato et al. 1992) in the presence of glucose, insulin release was still possible. This was also demonstrated in mice with genetically disrupted or deleted $\mathrm{K}^{+}$channels and pointed to an additional secretory mechanism that regulated sustained insulin release (Miki et al. 1998, Remedi et al. 2006). Termed $\mathrm{K}_{\mathrm{ATP}}$ independent GSIS, this mechanism is initiated by TCA intermediates and associated products (anaplerosis), phospholipase C/protein kinase C (PKC) signalling, alterations in intracellular levels of lipids and/or elevation in cAMP levels, together enhancing cytosolic $\mathrm{Ca}^{2+}$ flux and exocytosis (Sugden \& Holness 2011, Komatsu et al. 2013). Furthermore, various reports have suggested that multiple coupling factors may amplify $\mathrm{K}_{\mathrm{ATP}}$-independent GSIS, such as NADPH, NADH, glutamate and malonyl-CoA (Komatsu et al. 2001). As the precise biochemical mechanisms of $\mathrm{K}_{\mathrm{ATP}}{ }^{-}$ dependent and -independent GSIS are not the sole focus of this article, readers are advised to refer to recent review

Published by Bioscientifica Ltd 


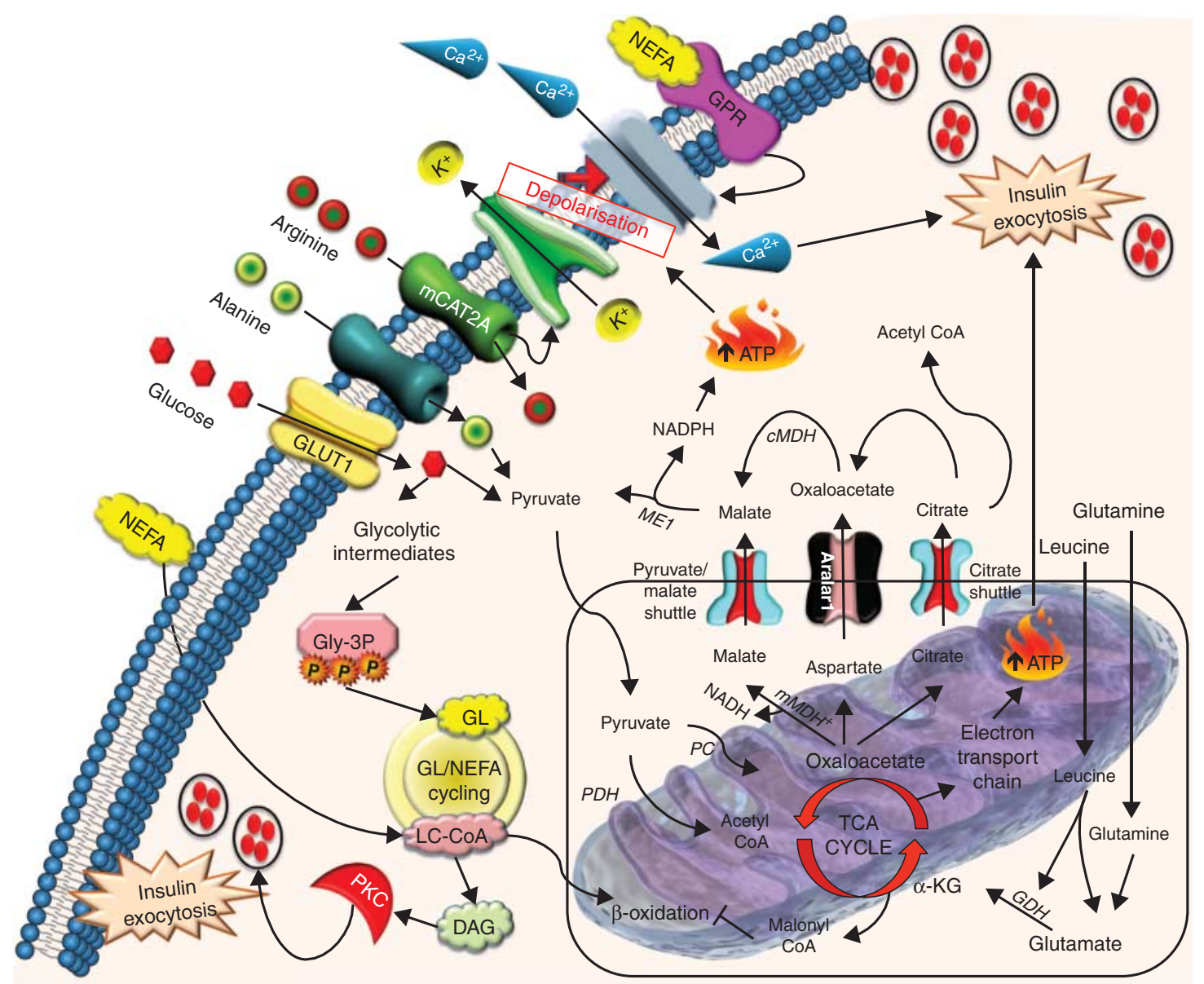

\section{Figure 1}

Mechanisms of nutrient stimulus-secretion coupling in the pancreatic $\beta$-cell. Nutrients promote insulin exocytosis by a variety of mechanisms, including plasma membrane depolarisation by enhancement of the ATP:ADP ratio via glycolytic and TCA metabolism and generation of reducing equivalents and production of lipid signalling molecules that promote vesicle trafficking and calcium influx. GPR, G-protein-coupled

articles (Fu et al. 2013, Komatsu et al. 2013) for more detail. However, it is clear that $\beta$-cell nutrient metabolism is central and critical to the insulin secretory mechanism described above, and consequently elevated glucose and lipid levels, as observed in T2DM patients, can chronically impact insulin secretion. Thus, the impact of specific nutrient groups on pancreatic $\beta$-cell insulin secretion will be discussed.

\section{Carbohydrate metabolism and insulin secretion}

The 'fuel-sensing' $\beta$-cell is exquisitely designed to release insulin when stimulated by dietary nutrients, particularly glucose. Several adaptions allow continuous monitoring of the plasma glucose load, and these are coupled to rapid receptor; NEFA, non-esterified fatty acids; GL, glycerolipid; Gly-3, glycerol-3-phosphate; LC-CoA, long-chain CoA; DAG, diacylglycerol; PKC, protein kinase $\mathrm{C}$; TCA, tricarboxylic acid; $\alpha-K G$, $\alpha$-ketoglutarate; $P D H$, pyruvate dehydrogenase; $P C$, pyruvate carboxylase; $G D H$, glutamate dehydrogenase; $M E 1$, malic enzyme 1; $C M D H$, cytosolic malate dehydrogenase; $m M D H$, mitochondrial malate dehydrogenase.

oxidative and anaplerotic metabolism, which transduces the elevated nutrient signal and maximises ATP generation for insulin exocytosis. These features include the ability to 'sense' glucose in the physiological range with high $K_{\mathrm{m}}$ glucose transporters and the 'glucokinase' enzyme (2-20 mmol/l), reduced expression of lactate dehydrogenase (LDH), high expression of redox shuttles to regenerate reducing equivalents, and increased pyruvate dehydrogenase (PDH) and pyruvate carboxylase (PC) activity, that ensure efficient oxidative metabolism in the presence of high glucose (Newsholme \& Krause 2012).

The influx of glucose is regulated by specific insulinindependent GLUT membrane transporter proteins (GLUT1 (SLC2A1) in human and GLUT2 in rodent $\beta$-cells) (De Vos et al. 1995, McCulloch et al. 2011, Rorsman

Published by Bioscientifica Ltd. 


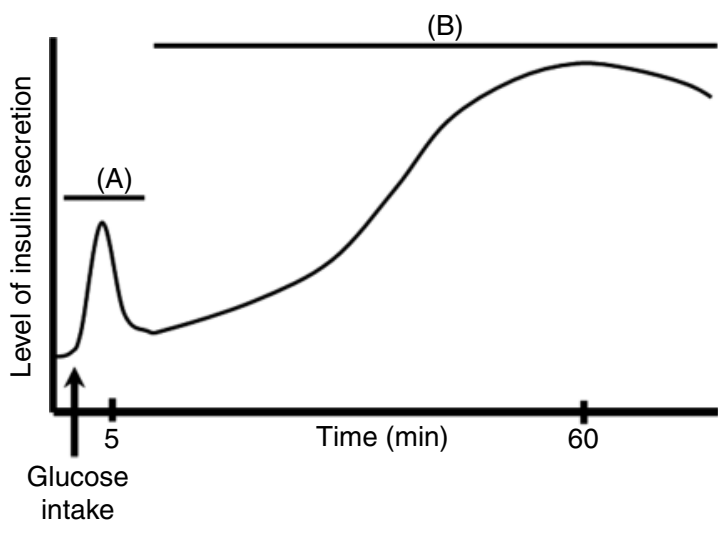

Figure 2

The pancreatic $\beta$-cell biphasic insulin secretion response. After administration of stimulatory levels of glucose, $\beta$-cell insulin secretion is immediately initiated and follows biphasic kinetics. The initial phase of insulin secretion (A) is rapid and is dependent on generation of ATP and the subsequent intracellular influx of calcium ions. The second, prolonged secretion of insulin (B) is dependent on mitochondrial metabolism, generation of coupling factors and calcium influx.

\& Braun 2013). The $K_{\mathrm{m}}$ of these GLUT1 and GLUT2 transporters for glucose is high $(6$ and $11 \mathrm{mM}$ respectively), indicating that they are only active at high extracellular glucose, as observed in postprandial conditions. Following glucose uptake, glycolytic degradation to pyruvate generates ATP, which is an important stimulus-secretion coupling factor as outlined above. Glucokinase (GCK) is a sophisticated hexokinase enzyme that also acts as a glucose sensor and has a high $K_{\mathrm{m}}$ for glucose $(6 \mathrm{mM})$. However, unlike other hexokinases, it is not inhibited by its product glucose-6-phosphate and maintains high glycolytic flux in the presence of elevated glucose, coupling carbohydrate sensing to insulin secretion in the $\beta$-cell (Bedoya et al. 1986, Alvarez et al. 2002, Newsholme \& Krause 2012). Alterations in the activity of important glycolytic enzymes such as GCK and phosphofructokinase can modulate GSIS, and this may lead to impaired glucose metabolism and insulin secretion (Nielsen et al. 1998, Westermark \& Lansner 2003, Gloyn et al. 2005). Furthermore, chronic hyperglycaemic conditions, as observed in T2DM, can negatively regulate the expression of several important glucose metabolising $\beta$-cell genes including SLC2A2, GCK, $\mathrm{Ca}^{2+}$ channels and insulin transcription factors pancreatic and duodenal homoeobox 1 (Pdx1), neurogenic differentiation 1 (NeuroD1) and v-maf musculoaponeurotic fibrosarcoma oncogene homologue A (MafA) (Cnop et al. 2005, Newsholme et al. 2010). In the diabetic state, reduced expression of these gene products leads to reduced glucose utilisation by the $\beta$-cells and consequently insulin-sensitive tissues. The decrease in glucose disposal by these tissues maintains elevated plasma glucose, which propagates glucotoxic conditions.

Interestingly, glycolytic intermediates may be diverted from glycolytic processes via the glycerol3-phosphate (Gly-3-P) shuttles and impact on insulin secretion (Fig. 1). Gly-3-P formation from fructose 1,6bisphosphate can enhance glycerolipid/non-esterified fatty acid (GL/NEFA) cycling, which promotes insulin secretion via generation of lipid signalling molecules such as long-chain acyl-CoA (LC-CoA) and diacylglycerol (DAG) (Fig. 1; Nolan \& Prentki 2008, Newsholme et al. 2010). Furthermore, Gly-3-P can be converted to dihydroxyacetone phosphate on entry into the mitochondria by mitochondrial Gly-3-P dehydrogenase (mGPDH), which generates $\mathrm{FADH}_{2}$ and thereby contributes to ATP production (Jitrapakdee et al. 2010).

As pancreatic $\beta$-cells express low levels of $\mathrm{LDH}$, they mostly recycle $\mathrm{NAD}^{+}$by expressing high levels of mitochondrial redox shuttles (NADH/NADPH) such as pyruvate/malate and pyruvate/citrate (Maassen et al. 2006). Central to the operation of pyruvate shuttles is the production of oxaloacetate from pyruvate by PC (Fig. 1). Oxaloacetate is converted to malate by mitochondrial malate dehydrogenase and enters the cytosol from the mitochondria. Malic enzyme 1 (ME1) regenerates pyruvate from malate (created from oxaloacetate), while simultaneously creating NADPH (Fig. 1). Pyruvate can then re-enter the mitochondria to continue the process, generating more NADH and increasing ATP levels (Jitrapakdee et al. 2010). Alternatively, oxaloacetate can be transferred to the cytosol by first condensing with acetyl CoA (provided by PDH) to form citrate, which is then translocated via the citrate carrier (Fig. 1). Citrate is converted back to oxaloacetate and acetyl CoA, and ME1 generates NADPH as described above, while acetyl CoA promotes NEFA accumulation through malonyl-CoA formation (dependent on acetyl CoA carboxylase (ACC)) and subsequent insulin secretion (Jitrapakdee et al. 2010). Understandably, studies have shown that siRNA knockdown of $P c(P c x)$ in murine models reduces $\beta$-cell proliferation and GSIS (Hasan et al. 2008, Xu et al. 2008), while enhanced expression increases GSIS (Xu et al. 2008), thus illustrating the importance of key $\beta$-cell enzymes for insulin secretion via participation in NADH redox shuttles.

Another vital redox shuttle that regulates reducing equivalent regeneration and consequently ATP production in $\beta$-cells is the malate/aspartate shuttle, along with the mitochondrial malate/2-oxoglutarate and

Published by Bioscientifica Ltd. 
aspartate/glutamate carriers. Cytosolic malate dehydrogenase (cMDH) converts oxaloacetate to malate and $\mathrm{NAD}^{+}$, and malate enters the mitochondrion via the malate/2-oxoglutarate. Here, it is oxidised back to oxaloacetate by mitochondrial MDH $(\mathrm{mMDH})$, while $\mathrm{NAD}^{+}$is reduced to NADH (Fig. 1). Mitochondrial oxaloacetate can then be transaminated to aspartate in the presence of glutamate and return to the cytosol through the aspartate/glutamate carrier, Aralar1 (Fig. 1; Newsholme et al. 2007a). This carrier plays an important role in mediating GSIS, and deletion in INS- $1 \beta$-cells was shown to elicit a complete loss of malate/aspartate shuttle activity and a 25\% decrease in insulin secretion (Marmol et al. 2009). By contrast, enhanced expression of Aralar1 improves GSIS and amino acid-stimulated insulin secretion in BRIN-BD11 cells (Bender et al. 2009).

Finally, current reports have suggested that $\beta$-cells express carbohydrate receptors that may directly signal to factors that regulate insulin secretion. Nakagawa et al. (2009) have shown that the murine $\beta$-cell line MIN6 expressed the functional sweet taste receptors T1R2 (TAS1R2) and T1R3 (TAS1R3), which are normally expressed in enteroendocrine cells and taste buds of the tongue. The MIN6 $\beta$-cell line was able to respond to a variety of receptor carbohydrate agonists, such as sucralose, by enhancing insulin secretion. Furthermore, other artificial sweeteners could modulate GSIS in this cell line, and evidence was provided to show that changes in insulin secretion were modulated through alterations in $\beta$-cell $\mathrm{Ca}^{2+}$ and/or cAMP handling (Nakagawa et al. 2013). Although not clearly understood, these data implicate a direct role for carbohydrate-mediated G-protein-coupled receptor (GPR) activity and signalling in the regulation of insulin secretion from the $\beta$-cell.

Taken together, carbohydrates impact on insulin secretion through a variety of mechanisms, and central to these is the generation of ATP and enhancement of mitochondrial metabolism including generation of NADH and $\mathrm{FADH}_{2}$. However, metabolism of other nutrient classes such as amino acids and lipids can also impact insulin secretion and this is discussed in the following sections.

\section{Amino acid metabolism and insulin secretion}

Anabolic and catabolic metabolism of amino acids is critical for a variety of cellular functions including protein and nucleotide synthesis. However, amino acids as a nutrient source are also key modulators of pancreatic $\beta$-cell insulin secretion. They can elicit either positive and/or negative effects on insulin release in vitro and in vivo, and this is mostly dependent on the amino acid type, duration of exposure and concentration (Newsholme $\&$ Krause 2012). Interestingly, amino acids administered alone at physiological concentrations do not modulate GSIS, but supplied in specific combinations at physiological concentrations or individually at elevated concentrations can elevate GSIS (Newsholme et al. 2007a, Newsholme \& Krause 2012). Amino acids regulate both the triggering and amplification pathways of insulin secretion by i) acting as a substrate for the TCA cycle and/or redox shuttles with subsequent generation of ATP, ii) direct depolarisation of plasma membrane by transport of positively charged amino acids into the cell via specific amino acid membrane transporters and iii) co-transport of $\mathrm{Na}^{+}$ions along with the amino acid on entry into the cell, resulting in plasma membrane depolarisation (Nolan \& Prentki 2008, Newsholme et al. 2010).

Glutamine is the most abundant amino acid in blood and extracellular fluids (Nolan \& Prentki 2008, Newsholme et al. 2010). Cell culture medium is regularly supplemented with glutamine to maintain cell proliferation and function in vitro. It is consumed at a rapid rate by many cell types including $\beta$-cells (Dixon et al. 2003). However, glutamine does not increase insulin exocytosis when administered alone (Dixon et al. 2003, Newsholme et al. 2010, Newsholme \& Krause 2012). Moreover, pharmacological impairment of glutamine metabolism attenuates GSIS (Li et al. 2004, Newsholme et al. 2010). Thus, the high demand and uptake of glutamine by $\beta$-cells indicate that it is essential for other cellular processes, perhaps protein, pyrimidine and purine synthesis (Newsholme et al. 2007a, Newsholme \& Krause 2012). Glutamine metabolism leads to aspartate and glutamate production (Brennan et al. 2003), and when administered in combination with leucine, insulin exocytosis is increased through activation of glutamate dehydrogenase $(\mathrm{GDH})$ and entry of glutamine carbon into the TCA cycle (Fig. 1; Henquin 2000, Newsholme et al. 2007a), enhancing the formation of reducing equivalents and activation of mitochondrial carrier proteins (Fig. 1; Sener \& Malaisse 1980, Nolan \& Prentki 2008).

Production of glutamate from glutamine may also contribute to $\beta$-cell antioxidant defence with entry into the $\gamma$-glutamyl cycle, thereby enhancing glutathione synthesis (Brennan et al. 2003, Newsholme \& Krause 2012). Therefore, glutamine derivatives possibly protect $\beta$-cells from oxidative insult. Interestingly, glutamate may also play a significant role in mediating insulin secretion directly, but the exact mechanisms are not entirely clear due to inconsistent observations published in the

Published by Bioscientifica Ltd. 
literature. Increased glutamate levels have been detected following exposure to glucose in islets and $\beta$-cell lines (Brennan et al. 2002, Broca et al. 2003), but others did not detect any significant changes (Danielsson et al. 1970, MacDonald \& Fahien 2000). Indeed, glutamate can accumulate within insulin vesicles and, potentially, be transported into the surrounding matrix during insulin exocytosis (Hoy et al. 2002, Newsholme \& Krause 2012). Glutamate released in this way may influence $\beta$-cell glutamate receptor activation (Corless et al. 2006). In addition, it may regulate glucagon secretion from adjacent glutamate-sensitive pancreatic $\alpha$-cells and is possibly an additional paracrine regulatory mechanism for maintenance of blood carbohydrate levels (Corless et al. 2006).

Alanine and arginine have also been noted to stimulate insulin secretion significantly. We have consistently shown that alanine is consumed by $\beta$-cell lines and islet cells and increases insulin secretion (Dixon et al. 2003, Newsholme et al. 2010, Newsholme \& Krause 2012, Salvucci et al. 2013), findings that are supported by observations from other $\beta$-cell lines including murine and human (Dunne et al. 1990, McCluskey et al. 2011, Kasabri et al. 2012). More recently, we have created an integrated mathematical model which predicted that increased intracellular ATP and $\mathrm{Ca}^{2+}$ levels were critical for glucose plus amino acid-stimulated insulin secretion in BRIN-BD11 cells (Salvucci et al. 2013). Furthermore, additional analyses demonstrated that alanine-mediated $\mathrm{Na}^{+}$co-transport acted synergistically with membrane depolarisation and

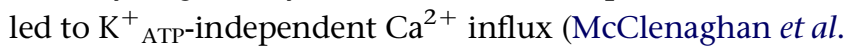
1998, Newsholme \& Krause 2012, Salvucci et al. 2013). However, the mechanism of action of alanine-induced insulin secretion is multifactorial and includes conversion to pyruvate (Salvucci et al. 2013), glutamate, aspartate and lactate (Fig. 1; Newsholme et al. 2010).

Arginine-induced insulin secretion is dependent on changes in plasma membrane potential, leading to opening of $\mathrm{Ca}^{2+}$ ion channels, $\mathrm{Ca}^{2+}$ influx and ultimately insulin exocytosis (McClenaghan et al. 1998, Sener et al. 2000, Newsholme \& Krause 2012). Arginine, a positively charged amino acid, enters the $\beta$-cell via the electrogenic transporter mCAT2A causing direct depolarisation of the membrane (Fig. 1; Newsholme \& Krause 2012). Interestingly, physiological concentrations of arginine have a cytoprotective role and attenuate cytokine-mediated apoptosis in $\beta$-cells, while partially boosting insulin secretion (Krause et al. 2011). This was facilitated by the conversion of arginine to glutamate, with enhancement of antioxidant levels (Krause et al. 2011). However, negative effects of high concentrations of arginine have been reported and these stem from the effect of enhancing velocity of inducible nitric oxide synthase (iNOS) through substrate stimulation, which may be harmful to the $\beta$-cell if cellular antioxidant defences are overwhelmed (Newsholme \& Krause 2012).

Finally, branched-chain amino acids (BCAAs), consisting of leucine, isoleucine and valine, are also reported to play an influential role in mediating insulin exocytosis (Newsholme \& Krause 2012, Gaudel et al. 2013), while enhanced plasma levels correlated with increased IR in the presence of elevated lipids (Newgard 2012, Lu et al. 2013). Interestingly, consumption of dairy products, which are a rich source of BCAAs, has been associated with improvements in both weight loss and T2DM management (Tremblay \& Gilbert 2009, Jakubowicz $\&$ Froy 2013); consumption of whey protein hydrolysates have been suggested to improve fasting insulin levels, insulin release and glycaemic control in in vivo animal models and in obese and T2DM human subjects (Gaudel et al. 2013, Jakubowicz \& Froy 2013). However, the precise mechanism of these positive effects are not fully understood, but are believed to involve increased protein synthesis and possibly thermogenesis via activation of mammalian target of rapamycin (mTOR) signalling, increased anaplerosis and, in the case of leucine, enhanced allosteric activation of GDH that leads to increased TCA activity in the $\beta$-cell (Fig. 1; Yang et al. 2006, Newsholme et al. 2010, Jakubowicz \& Froy 2013). Conversely, recent reports utilising metabolomic profiling have suggested that BCAA catabolism is associated with decreased insulin sensitivity in obese patients (Newgard et al. 2009). Comparable in vivo data showed that while animals on a high-fat diet with BCAAs (HF/BCAAs) did not consume as much food as animals receiving high fat alone (HF), they were as insulin resistant as this HF group, but retained a similar body weight to that of standard chow animals. In addition, chronic activation of mTOR by BCAAs, along with increased phosphorylation of insulin receptor substrate 1 (IRS1) in skeletal muscle, potentially promoted IR (Newgard et al. 2009). The accumulation of acylcarnitines from BCAA catabolism and their interplay with these signalling mechanisms appear to be of critical importance. However, while progress has been made to identify the precise effects of BCAAs on insulin release and action, more work is required to fully understand the mechanisms underlying the links between BCAAs and the development of metabolic disease. In conclusion, published evidence suggests that several key amino acids play a crucial role in mediating insulin secretion in a range of $\beta$-cell models and that these effects

Published by Bioscientifica Ltd 
are mediated through a variety of biochemical and physiological mechanisms. Potentially, the positive effects of amino acids may be harnessed to combat DM progression and aid DM management.

\section{Lipid metabolism and insulin secretion}

Lipids and NEFAs are crucial for $\beta$-cell function and insulin release, but elevated extracellular levels, usually associated with dyslipidaemia, are also associated with IR, $\beta$-cell failure and T2DM (Nolan et al. 2006a). In fasting or starvation, lipids are metabolised by $\beta$-oxidation in the mitochondria to produce ATP in many cells and tissues including liver and muscle (Newsholme et al. 2010). Entry into the mitochondria, where $\beta$-oxidation occurs, is regulated by a series of enzymatic and shuttle mechanisms (Hamilton \& Kamp 1999). Cytosolic NEFAs are first converted to LC-CoA by acyl-CoA synthase (ACS) and then translocated to the mitochondrial matrix by the action of carnitine palmitoyltransferases 1 and 2 (CPT1 and CPT2) (Berne 1975, Newsholme \& Krause 2012). In the matrix, LC-CoA molecules are oxidised to produce $\mathrm{CO}_{2}, \mathrm{NADH}$ and $\mathrm{FADH}_{2}$, and thus ATP. In the pancreatic $\beta$-cell, in the presence of sufficient nutrients, NEFAs can influence insulin secretion by three distinct metabolic signalling mechanisms. This 'trident model' was first described by Nolan et al. (2006a) and includes TCA/ malonyl-CoA metabolic signalling, GL/NEFA cycling and direct activation of GPRs (Fig. 1).

CPT activity and TCA/malonyl-CoA metabolism are closely connected to the regulation of $\beta$-oxidation. In the presence of NEFAs and excess carbohydrate, CPT activity is directly inhibited by the formation of malonyl-CoA from TCA intermediates by ACC (Fig. 1; Carpentier et al. 2000, Nolan et al. 2006a). Subsequently, accumulation of cytosolic lipids can enhance insulin secretion by i) altering the activity of regulatory ion channel proteins, ii) increasing $\mathrm{Ca}^{2+}$ influx, iii) generating insulinotropic lipids including LC-CoA and DAG and iv) enhancing insulin vesicle interaction with the plasma membrane (Deeney et al. 2000, Haber et al. 2006, Newsholme et al. 2010, Newsholme \& Krause 2012). Crucially, AMP-activated protein kinase (AMPK) is central to the regulation of NEFA metabolism and reduces the levels of malonylCoA by inhibiting ACC and enhancing malonyl-CoA decarboxylase (MCD) activity (Ruderman \& Prentki 2004, Nolan et al. 2006a, Newsholme \& Krause 2012). AMPK is sensitive to the cell energy status and is stimulated by a high AMP:ATP ratio, and thereby increasing $\beta$-oxidation (Nolan et al. 2006a). Interestingly, overexpression of MCD
(MLYCD) in the presence of NEFAs significantly reduced GSIS in INS832/13 $\beta$-cells and islets, which demonstrated the importance of AMPK, malonyl-CoA and lipid metabolism to insulin secretion (Mulder et al. 2001, Roduit et al. 2004, Nolan et al. 2006a).

Cycling of GL/NEFA in $\beta$-cells also impacts upon insulin exocytosis and is a convergence point of glucose and NEFA metabolism. Formation of Gly-3-P from inbound glucose (25\%) and generation of NEFAs, GLs and LC-CoA by lipolysis amplify the insulin secretory response in elevated glucose (Fig. 1). NEFA esterification and lipolysis can be initiated simultaneously in $\beta$-cells by glucose challenge in the presence of NEFA, while $\beta$-oxidation is inhibited (Nolan et al. 2006a,b). This mechanism provides insulinotropic lipid signalling molecules that aid vesicle manufacture and exocytosis. Specifically, DAG and LC-CoA enhance the exocytotic function of key vesicle priming and docking proteins such as MUNC13, synaptosomal-associated protein 25 (SNAP25) and synaptotagmin, while also modulating signal transduction by PKC activity (Fig. 1; Nolan et al. 2006a, Newsholme et al. 2007b, Nolan \& Prentki 2008, Newsholme et al. 2010, Rorsman \& Braun 2013). The main advantages of GL/NEFA cycling are that conversion of glucose to Gly-3-P protects $\beta$-cells and deviates inbound glucose carbon away from excessive oxidative metabolism, and offers an alternative mechanism to generate supplementary secretion coupling factors that are independent of TCA cycle and oxidative processes (Nolan \& Prentki 2008).

Lipids also augment insulin secretion through activation of GPRs (Shapiro et al. 2005), and recent reports have demonstrated that they are highly expressed in $\beta$-cells (Shapiro et al. 2005, Tomita et al. 2006, Newsholme \& Krause 2012). Isoforms including GPR40 (FFAR1), GPR41 (FFAR3), GPR119 and GPR120 (FFAR4) are important in $\beta$-cell physiology (Newsholme \& Krause 2012), and reduced levels or knockdown in rat $\beta$-cells, islets and Gpr40-deficient mice was shown to lower NEFA-induced amplification of GSIS (Itoh et al. 2003, Latour et al. 2007). It is believed that NEFA activation of GPRs leads to GSIS amplification through alterations in $\mathrm{Ca}^{2+}$-handling mechanisms, including efflux from the endoplasmic reticulum (ER) (Nolan \& Prentki 2008), and appears to be dependent on glucose-mediated activation of L-type calcium channels (Fig. 1; Shapiro et al. 2005, Nolan \& Prentki 2008). Interestingly, current evidence has examined the use of GPR agonists as potential therapeutic treatments for hyperglycaemia in T2DM patients, and TAK-875 was shown to reduce HbA1c and hypoglycaemic

Published by Bioscientifica Ltd 
effects in DM patients (Burant et al. 2012). Indeed, dietary supplementation with $\omega 3$ fatty acids may also promote insulin sensitisation and anti-inflammatory effects, as shown in obese mice models, and this appears to be facilitated by interaction with GPR120 (Oh et al. 2010).

The insulinotropic effects of NEFAs are dependent on lipid type, level of saturation, length of the carbon chain, and whether treatment is under acute or chronic conditions (Newsholme \& Krause 2012). Palmitic acid and stearic acid, both saturated NEFAs, can chronically decrease GSIS in vitro (Hosokawa et al. 1997, Keane et al. 2011), while unsaturated oleic acid or arachidonic acid enhances insulin secretion (Vassiliou et al. 2009, Keane et al. 2011). However, prolonged exposure of $\beta$-cells to high circulatory lipid levels, such as in T2DM, impairs glucose oxidation and consequently results in an increased AMP:ATP ratio and AMPK activation (Newsholme \& Krause 2012). As fatty acid oxidation is promoted, fatty acid synthesis is inhibited along with NEFA-mediated amplification of insulin secretion (Newsholme \& Krause 2012). In this scenario, AMPK functions to promote oxidation and avoids the toxic effect of the incoming lipids, mirroring the effect of physical activity, but at the cost of decreased insulin secretion (Towler \& Hardie 2007). This is particularly important when high glucose and high lipid levels are present together, potentially contributing to glucolipotoxicity.

In addition, inhibition of AMPK activity leads to cytosolic accumulation of lipids and these may also promote lipotoxicity by inducing ER stress and ceramide formation (Lang et al. 2011). Studies have shown that chronic palmitic acid exposure has a deleterious effect on $\beta$-cell ER morphology, depletes ER $\mathrm{Ca}^{2+}$ levels and causes increased NEFA esterification, which impair processing/ transport functions of the ER and ultimately cause ER stress (Cnop 2008, Cunha et al. 2008). Moreover, ceramide has been shown to be toxic to $\beta$-cells and islets (Lupi et al. 2002, Lang et al. 2011). The precise pro-apoptotic mechanism is not fully understood, but ceramide is thought to contribute to detrimental cell signalling (Lang et al. 2011).

The chronic intracellular accumulation of lipids, particularly in the presence of high glucose, can elicit damaging effects in $\beta$-cells through excessive reactive oxygen species (ROS) generation by increased TCA metabolite turnover, enhanced electron transport chain activity and elevated ER stress (conditions resulting in glucolipotoxicity (for further details, see review Newsholme et al. (2012b))). Excessive ROS can activate key inflammation pathways including nuclear factor $\kappa$-light-chain-enhancer of activated $\mathrm{B}$ cells $(\mathrm{NF \kappa} \mathrm{B})$ and
c-Jun $\mathrm{NH}_{2}$-terminal kinase (JNK) signalling (Morgan \& Liu 2011). It is widely accepted that inflammation is a major mediator of islet dysfunction not only in T1DM, but also in T2DM (Turley et al. 2003, Donath \& Shoelson 2011, Bending et al. 2012). The inflammatory pathophysiology of pancreatic islets in T1DM and T2DM is characterised by the presence of immune cell infiltration, apoptotic islet cells, high expression of cytokines or adipokines (e.g. interleukin $1 \beta$ (IL1 $\beta$, IL1B)), tumour necrosis factor $\alpha$ (TNF $\alpha$ (TNF), leptin) and amyloid deposits (islet amyloid polypeptide, IAPP) (Donath et al. 2008). In fact, some researchers have reported that hyperglycaemic conditions can promote IL1 $\beta$ production from pancreatic islets (Maedler et al. 2002, Böni-Schnetzler et al. 2008), but this remains controversial, as others have failed to observe a similar response (Welsh et al. 2005). Interestingly, IAPP has been detected in 90\% of T2DM islets postmortem (Clark et al. 1988, Back et al. 2012), and we have shown that IAPP oligomers can activate and induce IL1 $\beta$ production from dendritic cells and macrophages in vitro (Masters et al. 2010). Other researchers have demonstrated that ceramide can promote IL1 $\beta$ production from macrophages in high-fat diets (Vandanmagsar et al. 2011) and that NEFAs can activate the NLRP3 inflammasome in haematopoietic cells leading to IR (Wen et al. 2011). These studies elegantly illustrate the connection between nutrient metabolism and inflammation. Our own recent work has revealed that activation of the inflammasome is dependent on both glucose and fatty acid metabolism in macrophages (Masters et al. 2010). The inflammasome is a protein complex that is responsible for generation of IL1 $\beta$ and IL18 from their immature structure to the active, mature state. Masters et al. also observed that both glucose and minimally modified LDL (mmLDL), which is elevated in T2DM (Yano et al. 2004), were required for full IAPPmediated 'priming' of NLRP3 inflammasomes in bone marrow-derived macrophages. The precise mechanism behind these observations remains unknown. However, interplay with Tlr4 appears to be vital, as 'priming' was not possible in $\mathrm{C} 3 \mathrm{H} / \mathrm{HeJ}$ mice with non-functional Tlr4 (Masters et al. 2010).

The role of the inflammasome in complex diseases has been reviewed recently (Masters 2013), and these data clearly implicate that nutrient metabolism plays an important function in mediating islet inflammation and possibly pancreatic $\beta$-cell death. Nutrient effects in $\beta$-cells are complex and elevated glucose and NEFA levels are primary risk factors in relation to inflammation, obesity and T2DM (Cunha et al. 2008). However, the impact of excess nutrients, high insulin and elevated IR in

Published by Bioscientifica Ltd. 
insulin-sensitive tissues is also critical in the progression of DM. Consequently, the influence of insulin action in target tissues and organs is discussed next.

\section{Nutrient metabolism and insulin action in target tissues}

\section{Skeletal muscle, insulin and nutrients}

Skeletal muscles play a major role in glucose metabolism, being responsible for $\sim 75 \%$ of whole-body insulinstimulated glucose uptake (Shulman et al. 1990, Corcoran et al. 2007). Maintenance of skeletal muscle represents an important factor related to quality and longevity of life.

A variety of muscle cell functions can be altered by chemical and mechanical stimuli, establishing a cause and effect in relation to glucose homoeostasis and insulin signalling (Newsholme et al. 2012a). In both T1DM and T2DM, skeletal muscle cells show an imbalance between protein synthesis and degradation, resulting in increased myofibrillar protein breakdown and muscle wasting (Russell et al. 2009), with a concomitant increase in glycated end products and vascular complications (Newsholme et al. 2011, Krause et al. 2012).

Once released by pancreatic $\beta$-cells into the circulation, insulin initiates its anabolic effects through binding of the transmembrane insulin receptor (IR) in target tissues. The IR is a heterotetrameric tyrosine kinase receptor composed of two chain subunits ( $\alpha$ - and $\beta$-chains) and is a member of the growth factor receptor family (Fig. 3). This interaction promotes the autophosphorylation of the receptor and activation of intracellular proteins known as insulin receptor substrates (IRSs). There are more than 13 different IRSs; however, isoforms 1 and 2 deserve more attention as they are widely distributed among different cell types and mainly activated in muscle tissue (Corcoran et al. 2007). IRS1, and to a lesser extent IRS2, promotes the phosphorylation of phosphoinositide 3-kinase (PI3K) and subsequent intracellular events, resulting in 3-phosphoinositide-dependent protein kinase 1 (PDK1) activation. This pathway is related to the glucose transport machinery via migration and activation of protein kinase $\mathrm{B}$ (PKB/Akt) and atypical PKC (aPKC) (White 2003). While there are three isoforms of $A k t, A k t 2$ is recognised as the most abundant isoform in insulin-sensitive tissues, promoting the translocation of GLUT4 to the cell membrane and, consequently increasing glucose uptake from the blood (Taniguchi et al. 2006). The essential role of $A k t 2$ in GLUT4 translocation was highlighted in Akt2 knockout mice, which exhibited increased IR (Cho et al. 2001).
Skeletal muscle protein synthesis is highly responsive to Akt signalling, with several effector pathways acting downstream, such as mTOR (Nader 2007), and the negative regulator of glycogen synthesis, glycogen synthase kinase 3 (GSK3), resulting in enhanced glycogen synthesis (van der Velden et al. 2007). Experimentally, it was shown that cultured myotubes exposed to growth factors demonstrated hypertrophy, and this was stimulated by pathways downstream of Akt/mTOR and resulted in attenuation of GSK3 activity (Rommel et al. 2001). Many initiation factor complexes (e.g. eIF2 and eIF4F), which are assembled from multiple subunits, are sensitive to activation by the mTOR cascade (Sartorelli \& Fulco 2004) or indirectly stimulated by an increase in cell volume that is promoted by glucose transport and storage (Usher-Smith et al. 2009). These pathways can also be activated by other extracellular nutrients, such as amino acids, especially leucine. More recently, glutamine availability was identified as a limiting step for the mTOR complex 1 (mTORC1) activation pathway, a major regulator of cell size and tissue mass in both normal and diseased states (Nicklin et al. 2009). Moreover, mTORC1 activation has been related to increased transport of amino acids in skeletal muscle, and thus protein synthesis (Fig. 3).

In skeletal muscle, amino acid transport can occur through systems such L-type $\left(\mathrm{Na}^{+}\right.$-independent), A-type $\left(\mathrm{Na}^{+}\right.$-dependent), proton-coupled amino acid transporter (PAT-type) and cationic amino acid transporter (CAT-type) (Palacin et al. 1998, Drummond et al. 2010, Nicastro et al. 2012). L- and A-type systems are sensitive to mTORC1 activation, which in turn may be activated by insulin and other growth factors (Roos et al. 2009, Drummond et al. 2010). In mammalian cells, mTORC1 is essential for the phosphorylation and activation of S6K1, which directly impacts cell growth via eukaryotic initiation factor translation complexes (Ma et al. 2008). AMPK will attenuate energy-requiring processes, such as protein synthesis, by interfering with anabolic signalling mediated by the PI3K-Akt-mTOR-S6K1 cascade, resulting in inhibition of protein synthesis (Ohanna et al. 2005, Nader 2007). Hence, glucose and amino acid availability may impact insulinmediated effects on muscle protein synthesis (Fig. 3).

The plasma levels of BCAAs and urea production are increased markedly with increased efflux of amino acids from muscle to splanchnic tissues (Nair et al. 1995, Newsholme et al. 2011). However, the plasma and muscular concentrations of some amino acids such as $\gamma$-aminobutyric acid (GABA), arginine and glutamine (Menge et al. 2010) are decreased in both insulin-resistant

Published by Bioscientifica Ltd. 


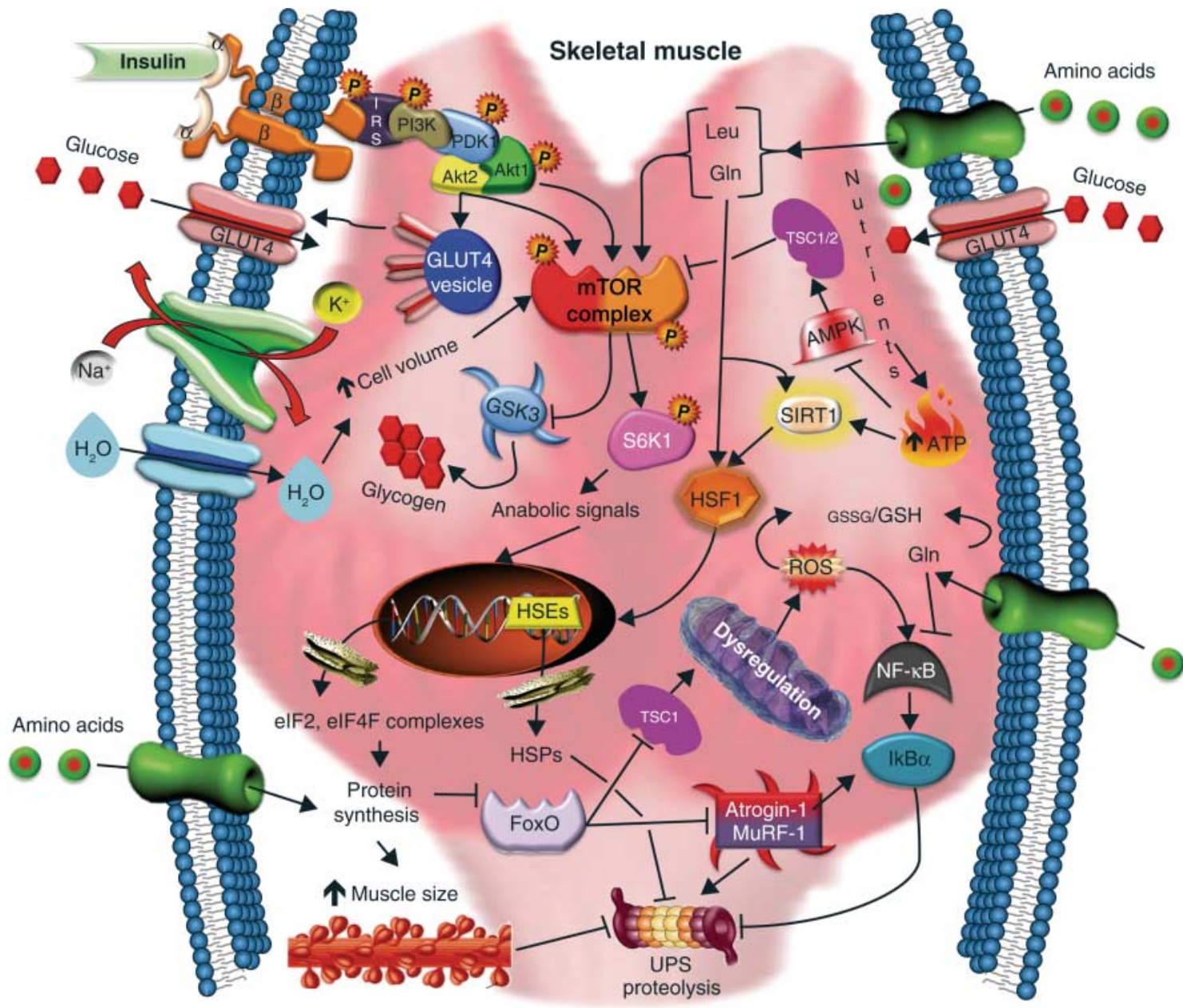

Figure 3

Canonical pathway mediated by insulin in skeletal muscle protein synthesis and degradation. Insulin binds to the insulin receptor, which initiates subsequent intracellular phosphorylation events through the PI3K-AktmTOR-S6K1 pathway, inhibiting the negative regulator of glycogen synthesis, GSK3, and stimulating glucose transport inside the cell. The gene expression of initiation factors begins to promote protein synthesis and inhibit protein degradation by FoxO-Atrogin1-MuRF1-UPS. Moreover, protein synthesis is dependent on amino acid availability and transport, especially leucine and glutamine. Glutamine may serve as a substrate for the de novo synthesis of GSH and possibly in the heat shock protein response via nutrient sensors such as SIRT1. IRS, insulin receptor substrate; PI3K, phosphoinositide 3-kinase; PDK1, phosphoinositide-dependent

and diabetic conditions, independent of the stage of the disease (Wijekoon et al. 2004, Menge et al. 2010, Newsholme et al. 2011).

The tripeptide glutathione (GSH, L- $\gamma$-glutamyl$\mathrm{L}$-cysteinylglycine) is the most important non-enzymatic soluble intracellular antioxidant and has many protective and metabolic functions in cellular metabolism, including attenuation of oxidative stress and inflammation (Cruzat \& Tirapegui 2009, Cruzat et al. 2010). However, kinase 1 ; AKT1, protein kinase $B$ or serine/threonine protein kinases 1 ; AKT2, protein kinase B or serine/threonine protein kinases 2; GLUT4, glucose transporter $4 ;$ mTOR, mammalian target of rapamycin; GSK3, glycogen synthase kinase 3; S6K1, ribosomal S6 kinase 1; Leu, L-leucine; GIn, L-glutamine; HSF1, heat shock factor 1; HSEs, heat shock elements; HSPs, heat shock proteins; elF2, eukaryotic initiation factor 2; elF4F, eukaryotic initiation factor 4F; FoxO, Forkhead box O; UPS, ubiquitin-proteasome system; TSC1/2, tuberous sclerosis 1 and 2; MURF1 (TRIM63), muscle RINGfinger protein 1; ROS, reactive oxygen species; GSSG, GSH, glutathione; AMPK, AMP-activated protein kinase; SIRT1, sirtuin 1; NFKB, nuclear factor $\kappa$-light-chain-enhancer of activated B cells; $1 \mathrm{kB} \alpha$, nuclear factor of $\kappa$ light polypeptide gene enhancer in B-cells inhibitor, alpha.

de novo synthesis of GSH is dependent on glutamine, the immediate precursor of glutamate (Cruzat et al. 2013). Recently, Krause et al. (2012) revealed that T2DM patients exhibited lower concentrations of nitrite and nitrate in skeletal muscle, which may contribute to elevated IR and partially explain muscle wasting in these circumstances (Newsholme et al. 2011). Moreover, the altered redox state of the cell and high inflammatory profile observed in diabetes may lead to activation of JNK, which is a key

Published by Bioscientifica Ltd. 
player in the progression of impaired insulin signalling in tissues such as skeletal muscle (Sabio et al. 2010, Zhang et al. 2011). Furthermore, glutamine is a potent modulator of the heat shock protein (HSP (HSP90B2P)) response, through the activation of the glucosamine pathway (Hamiel et al. 2009) and phosphorylation of eIF2. Indeed, glutamine may increase HSP70, BCL2 expression and GSH content, which may reduce TNF $\alpha$ - and IL1 $\beta$-induced injury and inflammation, an effect partially dependent on nitric oxide (NO) production (Newsholme et al. 2011). Although the mechanism is not completely understood, recent work has demonstrated that other HSPs, such as HSP27 (HSPB1) and HSP90 (HSP90AA1), operate as chaperones promoting protection (Cruzat et al. 2013, 2014). HSPs provide a protein management system including quality control of damaged proteins, such as those impacted by oxidation and degradation, via the ubiquitin-proteasome system (UPS) (Pratt et al. 2010).

\section{Adipose tissue and the liver}

Low-grade chronic inflammation is clearly linked to obesity-related metabolic diseases. The obesity/type 2 diabetes and inflammation connection was firmly established when, in 1993, a report was published demonstrating that the expression of TNF $\alpha$ in adipose tissue in mice was increased during the development of obesity, but on blocking TNF $\alpha$, IR was attenuated (Hotamisligil et al. 1993). It was subsequently determined that TNF $\alpha$ suppressed insulin signalling by inhibiting insulin receptor tyrosine kinase activity (Hotamisligil et al. 1996), thus attenuating insulin-driven changes in cell function and metabolism. Normally, insulin will drive fatty acid incorporation into triacylglycerol, utilising the substrate of Gly-3-P, which is derived from glucose. This ensures a coordinated uptake of fatty acids and glucose into adipose tissue, followed by esterification into triacylglycerol. Clearly, any interference in this process will lead to elevated circulating levels of glucose and fatty acids. Adipose tissue will release NEFAs and glycerol, under the action of various lipases, in periods of fasting, starvation and exercise.

In addition to secreted metabolites, adipose tissue can produce and release endocrine factors (adipokines). Leptin was identified in 1994 as a secretory bioactive molecule, which impacted food intake and energy expenditure through neuroendocrine circuits in the hypothalamus (Zhang et al. 1994). Adipokines are now known to alter the insulin sensitivity of the major insulin-sensitive organs, including liver and skeletal muscle, via the circulation. An impressively large number of adipokines have been identified (Tateya et al. 2013). TNF $\alpha$ and IL6 may be considered as adipokines under appropriate circumstances. TNF $\alpha$ activates pro-inflammatory signalling but attenuates insulin receptor signalling (Tateya et al. 2013), thus being the major factor linking adipose tissue inflammation with IR. By contrast, some other adipokines can promote insulin sensitivity and better control glucose homoeostasis. Adiponectin is an example of an adipokine that positively regulates insulin sensitivity. Adiponectin-deficient mice are severely insulin resistant (Tateya et al. 2013). Chronic adipose tissue inflammation can result in impairment of adipokine secretion, leading to systemic IR.

Macrophage accumulation in adipose tissue Macrophages are known to accumulate in adipose tissue in obesity and release pro-inflammatory cytokines such as TNF $\alpha$, which then impact on adipose tissue metabolism, including glucose and lipid metabolism (Tateya et al. 2013). TNF $\alpha$ and IL6 inhibit lipoprotein lipase, thus elevating triacylglycerol concentration in the blood and TNF $\alpha$ additionally stimulates hormone-sensitive lipase in adipose tissue, resulting in NEFA release into the blood. $\mathrm{TNF} \alpha$ also reduces insulin-stimulated glucose uptake via effects on GLUT4 translocation, as a result of impaired insulin signalling. All of these effects will tend to reduce lipid accumulation within adipose tissue, but increase blood lipid levels. Tateya et al. (2013) showed that macrophages defined as $\mathrm{F} 4 / 80^{+} \mathrm{CD}_{11} \mathrm{~b}^{+}$are resident in lean adipose tissue, representing $5 \%$ of the stromal vascular fraction, but may be increased in obesity by up to $30 \%$. Furthermore, they demonstrated that chronic weight loss reduced the macrophage content in adipose tissue, but fasting or acute weight loss elicited their accumulation.

Inflammatory activation of myeloid cells in the liver Macrophages are terminally differentiated cells of the mononuclear phagocyte system including dendritic cells, circulating blood monocytes and committed myeloid progenitor cells in the bone marrow. Macrophage activation is defined by a model that postulates two separate polarisation states, M1 (proinflammatory) and M2 (anti-inflammatory). In M1, classically activated macrophages will be formed on stimulation by inflammatory mediators such as lipopolysaccharide (LPS), TNF $\alpha$ and interferon $\gamma(\mathrm{IFN} \gamma)$, and in turn release $\mathrm{TNF} \alpha$, IL1 and IL6. In M2, alternatively activated macrophages have vastly reduced inflammatory characteristics but release high levels of anti-inflammatory cytokines, for example, IL10. As the attenuation of

Published by Bioscientifica Ltd. 
macrophage M1 activation and the maintenance of M2 activity are believed to be important for appropriate levels of glucose and lipid formation and release from the liver, stimuli which control the formation of one over the other form of macrophage are important for liver metabolism. $\mathrm{TNF} \alpha$, for example, increased hepatic lipogenesis due to a combination of inhibition of intracellular lipases and provision of intracellular fatty acids for triacylglycerol synthesis. Hepatic gluconeogenesis is also increased by $\mathrm{TNF} \alpha$, as well as reduced hepatocyte glycogen content, by a mechanism dependent on NAPDH oxidase 3 activation and ROS generation, leading to elevated blood glucose levels (Gao et al. 2010).

Consumption of a high-fat diet activated Kupffer's cells (the resident macrophages of the liver) in mice, resulting in an increased M1-polarised population; an event associated with the pathogenesis of obesity-induced IR and fatty liver disease (Gao et al. 2010). Interestingly, chemical deletion of Kupffer's cells improved insulin sensitivity during high-fat feeding. The range of immune cells in the liver is complex and heterogeneous, but it is clear that the Kupffer's cells contribute to both IR and hepatic steatosis.

In summary, diets rich in fat facilitate activation of macrophages, which then exert a negative influence on metabolic processes in both adipose tissue and liver during the onset of DM. Further, DM is associated with the production of monocytes from the bone marrow (Hu et al. 2013), thus contributing to inflammation and continued repression of insulin secretion and insulin signalling.

\section{Concluding remarks}

In conclusion, carbohydrate, lipid and amino acid metabolism plays an important role in regulating pancreatic $\beta$-cell insulin secretion. Furthermore, the nutrient handling capabilities of other insulin-sensitive tissues, such as skeletal muscle, adipocytes and liver, dictate the whole-body nutrient homoeostasis. However, nutrient overconsumption leads to an increased risk of $\beta$-cell dysfunction and impaired insulin action that is routinely observed in DM. The startling epidemic rise in obesity and diabesity, due to diminished physical activity and excessive consumption of carbohydrate- and lipid-laden diets, highlights the need for new therapies and strategies to combat increased DM. Consequently, further understanding of the complexities of $\beta$-cell function, insulin action and metabolism may generate novel targets and treatments for the metabolic syndrome.

\section{Declaration of interest}

The authors declare that there is no conflict of interest that could be perceived as prejudicing the impartiality of the review.

\section{Funding}

This research did not receive any specific grant from any funding agency in the public, commercial or not-for-profit sector.

\section{Acknowledgements}

We thank the School of Biomedical Sciences and Faculty of Health Sciences, Curtin University, Perth, Western Australia, for provision of excellent research facilities and support.

\section{References}

Alvarez E, Roncero I, Chowen JA, Vazquez P \& Blazquez E 2002 Evidence that glucokinase regulatory protein is expressed and interacts with glucokinase in rat brain. Journal of Neurochemistry $8045-53$. (doi:10.1046/j.0022-3042.2001.00677.x)

Back SH, Kang S-W, Han J \& Chung H-T 2012 Endoplasmic reticulum stress in the $\beta$-cell pathogenesis of type 2 diabetes. Experimental Diabetes Research 2012 618396-618396. (doi:10.1155/2012/618396)

Bedoya FJ, Wilson JM, Ghosh AK, Finegold D \& Matschinsky FM 1986 The glucokinase glucose sensor in human pancreatic islet tissue. Diabetes 35 61-67. (doi:10.2337/diab.35.1.61)

Bender K, Maechler P, McClenaghan NH, Flatt PR \& Newsholme P 2009 Overexpression of the malate-aspartate NADH shuttle member Aralar1 in the clonal $\beta$-cell line BRIN-BD11 enhances amino-acid-stimulated insulin secretion and cell metabolism. Clinical Science 117 321-330. (doi:10.1042/CS20090126)

Bending D, Zaccone P \& Cooke A 2012 Inflammation and type one diabetes. International Immunology 24 339-346. (doi:10.1093/intimm/ dxs049)

Berne C 1975 The metabolism of lipids in mouse pancreatic islets. The biosynthesis of triacylglycerols and phospholipids. Biochemical Journal $152667-673$.

Böni-Schnetzler M, Thorne J, Parnaud G, Marselli L, Ehses JA, Kerr-Conte J, Pattou F, Halban PA, Weir GC \& Donath MY 2008 Increased interleukin (IL)-1 $\beta$ messenger ribonucleic acid expression in $\beta$-cells of individuals with type 2 diabetes and regulation of IL-1 $\beta$ in human islets by glucose and autostimulation. Journal of Clinical Endocrinology and Metabolism 93 4065-4074. (doi:10.1210/jc.2008-0396)

Brennan L, Shine A, Hewage C, Malthouse JP, Brindle KM, McClenaghan N, Flatt PR \& Newsholme P 2002 A nuclear magnetic resonance-based demonstration of substantial oxidative L-alanine metabolism and L-alanine-enhanced glucose metabolism in a clonal pancreatic $\beta$-cell line: metabolism of L-alanine is important to the regulation of insulin secretion. Diabetes 51 1714-1721. (doi:10.2337/diabetes.51.6.1714)

Brennan L, Corless M, Hewage C, Malthouse JP, McClenaghan NH, Flatt PR $\&$ Newsholme P $2003{ }^{13} \mathrm{C}$ NMR analysis reveals a link between L-glutamine metabolism, D-glucose metabolism and $\gamma$-glutamyl cycle activity in a clonal pancreatic $\beta$-cell line. Diabetologia 46 1512-1521. (doi:10.1007/s00125-003-1184-7)

Broca C, Brennan L, Petit P, Newsholme P \& Maechler P 2003 Mitochondriaderived glutamate at the interplay between branched-chain amino acid and glucose-induced insulin secretion. FEBS Letters 545 167-172. (doi:10.1016/S0014-5793(03)00526-X)

Burant CF, Viswanathan P, Marcinak J, Cao C, Vakilynejad M, Xie B \& Leifke E 2012 TAK-875 versus placebo or glimepiride in type 2 diabetes

Published by Bioscientifica Ltd 
mellitus: a phase 2, randomised, double-blind, placebo-controlled trial. Lancet 379 1403-1411. (doi:10.1016/S0140-6736(11)61879-5)

Cabrera O, Berman DM, Kenyon NS, Ricordi C, Berggren PO \& Caicedo A 2006 The unique cytoarchitecture of human pancreatic islets has implications for islet cell function. PNAS 103 2334-2339. (doi:10.1073/ pnas.0510790103)

Carpentier A, Mittelman SD, Bergman RN, Giacca A \& Lewis GF 2000 Prolonged elevation of plasma free fatty acids impairs pancreatic $\beta$-cell function in obese nondiabetic humans but not in individuals with type 2 diabetes. Diabetes 49 399-408. (doi:10.2337/diabetes.49.3.399)

Cho H, Mu J, Kim JK, Thorvaldsen JL, Chu Q, Crenshaw EB III, Kaestner KH, Bartolomei MS, Shulman GI \& Birnbaum MJ 2001 Insulin resistance and a diabetes mellitus-like syndrome in mice lacking the protein kinase Akt2 (PKB ß). Science 292 1728-1731. (doi:10.1126/science.292. $5522.1728)$

Clark A, Wells CA, Buley ID, Cruickshank JK, Vanhegan RI, Matthews DR, Cooper GJ, Holman RR \& Turner RC 1988 Islet amyloid, increased A-cells, reduced B-cells and exocrine fibrosis: quantitative changes in the pancreas in type 2 diabetes. Diabetes Research 9 151-159.

Cnop M 2008 Fatty acids and glucolipotoxicity in the pathogenesis of type 2 diabetes. Biochemical Society Transactions 36 348-352. (doi:10.1042/BST0360348)

Cnop M, Welsh N, Jonas J-C, Jorns A, Lenzen S \& Eizirik DL 2005 Mechanisms of pancreatic $\beta$-cell death in type 1 and type 2 diabetes: many differences, few similarities. Diabetes 54(Suppl 2) 97-9107. (doi:10.2337/diabetes.54.suppl_2.S97)

Corcoran MP, Lamon-Fava S \& Fielding RA 2007 Skeletal muscle lipid deposition and insulin resistance: effect of dietary fatty acids and exercise. American Journal of Clinical Nutrition 85 662-677.

Corless M, Kiely A, McClenaghan NH, Flatt PR \& Newsholme P 2006 Glutamine regulates expression of key transcription factor, signal transduction, metabolic gene, and protein expression in a clonal pancreatic $\beta$-cell line. Journal of Endocrinology 190 719-727. (doi:10.1677/joe.1.06892)

Cruzat VF \& Tirapegui J 2009 Effects of oral supplementation with glutamine and alanyl-glutamine on glutamine, glutamate, and glutathione status in trained rats and subjected to long-duration exercise. Nutrition 25 428-435. (doi:10.1016/j.nut.2008.09.014)

Cruzat VF, Rogero MM \& Tirapegui J 2010 Effects of supplementation with free glutamine and the dipeptide alanyl-glutamine on parameters of muscle damage and inflammation in rats submitted to prolonged exercise. Cell Biochemistry and Function 28 24-30. (doi:10.1002/cbf. 1611)

Cruzat VF, Bittencourt A, Scomazzon SP, Leite JM, Homem de Bittencourt PI \& Tirapegui J 2014 Oral free and dipeptide forms of glutamine supplementations attenuate oxidative stress and inflammation induced by endotoxemia. Nutrition 30 602-611. (doi:10.1016/j.nut. 2013.10.019)

Cruzat VF, Pantaleão LC, Donato J, de Bittencourt PIH \& Tirapegui J 2014 Oral supplementations with free and dipeptide forms of L-glutamine in endotoxemic mice: effects on muscle glutamine-glutathione axis and heat shock proteins. Journal of Nutritional Biochemistry 25 345-352. (doi:10.1016/j.jnutbio.2013.11.009)

Cunha DA, Hekerman P, Ladriere L, Bazarra-Castro A, Ortis F, Wakeham MC, Moore F, Rasschaert J, Cardozo AK, Bellomo E et al. 2008 Initiation and execution of lipotoxic ER stress in pancreatic $\beta$-cells. Journal of Cell Science 121 2308-2318. (doi:10.1242/jcs.026062)

Danielsson A, Hellman B \& Idahl LA 1970 Levels of -ketoglutarate and glutamate in stimulated pancreatic -cells. Hormone and Metabolic Research 2 28-31. (doi:10.1055/s-0028-1095123)

Deeney JT, Gromada J, Hoy M, Olsen HL, Rhodes CJ, Prentki M, Berggren PO \& Corkey BE 2000 Acute stimulation with long chain acyl-CoA enhances exocytosis in insulin-secreting cells (HIT T-15 and NMRI $\beta$-cells). Journal of Biological Chemistry 275 9363-9368. (doi:10.1074/jbc. 275.13.9363)
De Vos A, Heimberg H, Quartier E, Huypens P, Bouwens L, Pipeleers D \& Schuit F 1995 Human and rat $\beta$ cells differ in glucose transporter but not in glucokinase gene expression. Journal of Clinical Investigation 96 2489-2495. (doi:10.1172/JCI118308)

Dixon G, Nolan J, McClenaghan N, Flatt PR \& Newsholme P 2003 A comparative study of amino acid consumption by rat islet cells and the clonal $\beta$-cell line BRIN-BD11 - the functional significance of L-alanine. Journal of Endocrinology 179 447-454. (doi:10.1677/joe.0.1790447)

Donath MY \& Shoelson SE 2011 Type 2 diabetes as an inflammatory disease. Nature Reviews. Immunology 11 98-9107. (doi:10.1038/nri2925)

Donath MY, Schumann DM, Faulenbach M, Ellingsgaard H, Perren A \& Ehses JA 2008 Islet inflammation in type 2 diabetes: from metabolic stress to therapy. Diabetes Care 31(Suppl 2) 161-164. (doi:10.2337/ dc08-s243)

Drummond MJ, Glynn EL, Fry CS, Timmerman KL, Volpi E \& Rasmussen BB 2010 An increase in essential amino acid availability upregulates amino acid transporter expression in human skeletal muscle. American Journal of Physiology. Endocrinology and Metabolism 298 E1011-E1018. (doi:10.1152/ ajpendo.00690.2009)

Dunne MJ, Yule DI, Gallacher DV \& Petersen OH 1990 Effects of alanine on insulin-secreting cells: patch-clamp and single cell intracellular $\mathrm{Ca}^{2+}$ measurements. Biochimica et Biophysica Acta 1055 157-164. (doi:10.1016/0167-4889(90)90116-U)

Flatt PR \& Lenzen S 1994 Frontiers of Insulin Secretion and Pancreatic B-Cell Research. London, UK: Smith-Gordon Limited.

Fu Z, Gilbert ER \& Liu D 2013 Regulation of insulin synthesis and secretion and pancreatic $\beta$-cell dysfunction in diabetes. Current Diabetes Reviews 9 25-53. (doi:10.2174/157339913804143225)

Gao D, Nong S, Huang X, Lu Y, Zhao H, Lin Y, Man Y, Wang S, Yang J \& Li J 2010 The effects of palmitate on hepatic insulin resistance are mediated by NADPH oxidase 3-derived reactive oxygen species through JNK and p38MAPK pathways. Journal of Biological Chemistry 285 29965-29973. (doi:10.1074/jbc.M110.128694)

Gaudel C, Nongonierma AB, Maher S, Flynn S, Krause M, Murray BA, Kelly PM, Baird AW, Fitzgerald RJ \& Newsholme P 2013 A whey protein hydrolysate promotes insulinotropic activity in a clonal pancreatic $\beta$-cell line and enhances glycemic function in ob/ob mice. Journal of Nutrition 143 1109-1114. (doi:10.3945/jn.113.174912)

Gembal M, Gilon P \& Henquin JC 1992 Evidence that glucose can control insulin release independently from its action on ATP-sensitive $\mathrm{K}+$ channels in mouse B cells. Journal of Clinical Investigation $\mathbf{8 9}$ 1288-1295. (doi:10.1172/JCI115714)

Gloyn AL, Odili S, Zelent D, Buettger C, Castleden HA, Steele AM, Stride A, Shiota C, Magnuson MA, Lorini R et al. 2005 Insights into the structure and regulation of glucokinase from a novel mutation (V62M), which causes maturity-onset diabetes of the young. Journal of Biological Chemistry 280 14105-14113. (doi:10.1074/jbc.M413146200)

Haber EP, Procopio J, Carvalho CR, Carpinelli AR, Newsholme P \& Curi R 2006 New insights into fatty acid modulation of pancreatic $\beta$-cell function. International Review of Cytology 248 1-41.

Hamiel CR, Pinto S, Hau A \& Wischmeyer PE 2009 Glutamine enhances heat shock protein 70 expression via increased hexosamine biosynthetic pathway activity. American Journal of Physiology. Cell Physiology 297 C1509-C1519. (doi:10.1152/ajpcell.00240.2009)

Hamilton JA \& Kamp F 1999 How are free fatty acids transported in membranes? Is it by proteins or by free diffusion through the lipids? Diabetes 48 2255-2269. (doi:10.2337/diabetes.48.12.2255)

Hasan NM, Longacre MJ, Stoker SW, Boonsaen T, Jitrapakdee S, Kendrick MA, Wallace JC \& MacDonald MJ 2008 Impaired anaplerosis and insulin secretion in insulinoma cells caused by small interfering RNA-mediated suppression of pyruvate carboxylase. Journal of Biological Chemistry $\mathbf{2 8 3}$ 28048-28059. (doi:10.1074/jbc.M804170200)

Henquin JC 2000 Triggering and amplifying pathways of regulation of insulin secretion by glucose. Diabetes 49 1751-1760. (doi:10.2337/ diabetes.49.11.1751) 
Hosokawa H, Corkey BE \& Leahy JL 1997 -cell hypersensitivity to glucose following 24-h exposure of rat islets to fatty acids. Diabetologia $\mathbf{4 0}$ 392-397. (doi:10.1007/s001250050692)

Hotamisligil GS, Shargill NS \& Spiegelman BM 1993 Adipose expression of tumor necrosis factor- $\alpha$ : direct role in obesity-linked insulin resistance. Science 259 87-91. (doi:10.1126/science.7678183)

Hotamisligil GS, Peraldi P, Budavari A, Ellis R, White MF \& Spiegelman BM 1996 IRS-1-mediated inhibition of insulin receptor tyrosine kinase activity in TNF- $\alpha$ - and obesity-induced insulin resistance. Science $\mathbf{2 7 1}$ 665-668. (doi:10.1126/science.271.5249.665)

Hoy M, Maechler P, Efanov AM, Wollheim CB, Berggren PO \& Gromada J 2002 Increase in cellular glutamate levels stimulates exocytosis in pancreatic $\beta$-cells. FEBS Letters 531 199-203. (doi:10.1016/ S0014-5793(02)03500-7)

Hu P, Thinschmidt JS, Yan Y, Hazra S, Bhatwadekar A, Caballero S, Salazar T, Miyan JA, Li W, Derbenev A et al. 2013 CNS inflammation and bone marrow neuropathy in type 1 diabetes. American Journal of Pathology 183 1608-1620. (doi:10.1016/j.ajpath.2013.07.009)

Itoh Y, Kawamata Y, Harada M, Kobayashi M, Fujii R, Fukusumi S, Ogi K, Hosoya M, Tanaka Y, Uejima $\mathrm{H}$ et al. 2003 Free fatty acids regulate insulin secretion from pancreatic $\beta$ cells through GPR40. Nature 422 173-176. (doi:10.1038/nature01478)

Jakubowicz D \& Froy O 2013 Biochemical and metabolic mechanisms by which dietary whey protein may combat obesity and type 2 diabetes. Journal of Nutritional Biochemistry 24 1-5. (doi:10.1016/j.jnutbio.2012. 07.008)

Jensen MV, Joseph JW, Ronnebaum SM, Burgess SC, Sherry AD \& Newgard CB 2008 Metabolic cycling in control of glucose-stimulated insulin secretion. American Journal of Physiology, Endocrinology and Metabolism 295 E1287-E1297. (doi:10.1152/ajpendo.90604.2008)

Jitrapakdee S, Wutthisathapornchai A, Wallace JC \& MacDonald MJ 2010 Regulation of insulin secretion: role of mitochondrial signalling. Diabetologia 53 1019-1032. (doi:10.1007/s00125-010-1685-0)

Kasabri V, Abu-Dahab R, Afifi FU, Naffa R \& Majdalawi L 2012 Modulation of pancreatic MIN6 insulin secretion and proliferation and extrapancreatic glucose absorption with Achillea santolina, Eryngium creticum and Pistacia atlantica extracts: in vitro evaluation. Journal of Experimental and Integrative Medicine 2 245-254.

Keane DC, Takahashi HK, Dhayal S, Morgan NG, Curi R \& Newsholme P 2011 Arachidonic acid actions on functional integrity and attenuation of the negative effects of palmitic acid in a clonal pancreatic $\beta$-cell line. Clinical Science 120 195-206. (doi:10.1042/CS20100282)

Komatsu M, Sato Y, Aizawa T \& Hashizume K 2001 KATP channelindependent glucose action: an elusive pathway in stimulus-secretion coupling of pancreatic $\beta$-cell. Endocrine Journal 48 275-288. (doi:10.1507/endocri.48.275)

Komatsu M, Takei M, Ishii H \& Sato Y 2013 Glucose-stimulated insulin secretion: a newer perspective. Journal of Diabetes Investigation 4 511-516. (doi:10.1111/jdi.12094)

Krause MS, McClenaghan NH, Flatt PR, de Bittencourt PIH, Murphy C \& Newsholme P 2011 L-arginine is essential for pancreatic $\beta$-cell functional integrity, metabolism and defense from inflammatory challenge. Journal of Endocrinology 211 87-97. (doi:10.1530/JOE-11-0236)

Krause M, Rodrigues-Krause J, O'Hagan C, De Vito G, Boreham C, Susta D, Newsholme P \& Murphy C 2012 Differential nitric oxide levels in the blood and skeletal muscle of type 2 diabetic subjects may be consequence of adiposity: a preliminary study. Metabolism 61 1528-1537. (doi:10.1016/j.metabol.2012.05.003)

Lang F, Ullrich S \& Gulbins E 2011 Ceramide formation as a target in $\beta$-cell survival and function. Expert Opinion on Therapeutic Targets 15 1061-1071. (doi:10.1517/14728222.2011.588209)

Latour MG, Alquier T, Oseid E, Tremblay C, Jetton TL, Luo J, Lin DC \& Poitout V 2007 GPR40 is necessary but not sufficient for fatty acid stimulation of insulin secretion in vivo. Diabetes 56 1087-1094. (doi:10.2337/db06-1532)
Li C, Buettger C, Kwagh J, Matter A, Daikhin Y, Nissim IB, Collins HW, Yudkoff M, Stanley CA \& Matschinsky FM 2004 A signaling role of glutamine in insulin secretion. Journal of Biological Chemistry 279 13393-13401. (doi:10.1074/jbc.M311502200)

Lu J, Xie G, Jia W \& Jia W 2013 Insulin resistance and the metabolism of branched-chain amino acids. Frontiers of Medicine 7 53-59. (doi:10.1007/s11684-013-0255-5)

Lupi R, Dotta F, Marselli L, Del Guerra S, Masini M, Santangelo C, Patane G, Boggi U, Piro S, Anello M et al. 2002 Prolonged exposure to free fatty acids has cytostatic and pro-apoptotic effects on human pancreatic islets: evidence that $\beta$-cell death is caspase mediated, partially dependent on ceramide pathway, and Bcl-2 regulated. Diabetes $\mathbf{5 1}$ 1437-1442. (doi:10.2337/diabetes.51.5.1437)

Ma XM, Yoon SO, Richardson CJ, Julich K \& Blenis J 2008 SKAR links pre-mRNA splicing to mTOR/S6K1-mediated enhanced translation efficiency of spliced mRNAs. Cell 133 303-313. (doi:10.1016/j.cell. 2008.02.031)

Maassen JA, t Hart LM, Janssen GM, Reiling E, Romijn JA \& Lemkes HH 2006 Mitochondrial diabetes and its lessons for common type 2 diabetes. Biochemical Society Transactions 34 819-823. (doi:10.1042/ BST0340819)

MacDonald MJ \& Fahien LA 2000 Glutamate is not a messenger in insulin secretion. Journal of Biological Chemistry 275 34025-34027. (doi:10.1074/jbc.C000411200)

Maedler K, Sergeev P, Ris F, Oberholzer J, Joller-Jemelka HI, Spinas GA, Kaiser N, Halban PA \& Donath MY 2002 Glucose-induced $\beta$ cell production of IL-1 $\beta$ contributes to glucotoxicity in human pancreatic islets. Journal of Clinical Investigation 110 851-860. (doi:10.1172/ JCI200215318)

Marmol P, Pardo B, Wiederkehr A, del Arco A, Wollheim CB \& Satrustegui J 2009 Requirement for aralar and its $\mathrm{Ca}^{2+}$-binding sites in $\mathrm{Ca}^{2+}$ signal transduction in mitochondria from INS-1 clonal $\beta$-cells. Journal of Biological Chemistry 284 515-524. (doi:10.1074/jbc.M806729200)

Masters SL 2013 Specific inflammasomes in complex diseases. Clinical Immunology 147 223-228. (doi:10.1016/j.clim.2012.12.006)

Masters SL, Dunne A, Subramanian SL, Hull RL, Tannahill GM, Sharp FA, Becker C, Franchi L, Yoshihara E, Chen Z et al. 2010 Activation of the NLRP3 inflammasome by islet amyloid polypeptide provides a mechanism for enhanced IL-1 $\beta$ in type 2 diabetes. Nature Immunology 11 897-904. (doi:10.1038/ni.1935)

McClenaghan NH, Barnett CR \& Flatt PR $1998 \mathrm{Na}+$ cotransport by metabolizable and nonmetabolizable amino acids stimulates a glucoseregulated insulin-secretory response. Biochemical and Biophysical Research Communications 249 299-303. (doi:10.1006/bbrc.1998.9136)

McCluskey JT, Hamid M, Guo-Parke H, McClenaghan NH, Gomis R \& Flatt PR 2011 Development and functional characterization of insulinreleasing human pancreatic $\beta$ cell lines produced by electrofusion. Journal of Biological Chemistry 286 21982-21992. (doi:10.1074/jbc. M111.226795)

McCulloch LJ, van de Bunt M, Braun M, Frayn KN, Clark A \& Gloyn AL 2011 GLUT2(SLC2A2) is not the principal glucose transporter in human pancreatic $\beta$ cells: implications for understanding genetic association signals at this locus. Molecular Genetics and Metabolism 104 648-653. (doi:10.1016/j.ymgme.2011.08.026)

Menge BA, Schrader H, Ritter PR, Ellrichmann M, Uhl W, Schmidt WE \& Meier JJ 2010 Selective amino acid deficiency in patients with impaired glucose tolerance and type 2 diabetes. Regulatory Peptides 160 75-80. (doi:10.1016/j.regpep.2009.08.001)

Miki T, Nagashima K, Tashiro F, Kotake K, Yoshitomi H, Tamamoto A, Gonoi T, Iwanaga T, Miyazaki J \& Seino S 1998 Defective insulin secretion and enhanced insulin action in KATP channel-deficient mice. PNAS 95 10402-10406. (doi:10.1073/pnas.95.18.10402)

Morgan MJ \& Liu ZG 2011 Crosstalk of reactive oxygen species and NF- $\kappa$ B signaling. Cell Research 21 103-115. (doi:10.1038/cr.2010.178)

Mulder H, Lu D, Finley JT, An J, Cohen J, Antinozzi PA, McGarry JD \& Newgard CB 2001 Overexpression of a modified human malonyl-CoA

Published by Bioscientifica Ltd 
decarboxylase blocks the glucose-induced increase in malonyl-CoA level but has no impact on insulin secretion in INS-1-derived $(832 / 13)$ $\beta$-cells. Journal of Biological Chemistry 276 6479-6484. (doi:10.1074/jbc. M010364200)

Nader GA 2007 Muscle growth learns new tricks from an old dog. Nature Medicine 13 1016-1018. (doi:10.1038/nm0907-1016)

Nair KS, Ford GC, Ekberg K, Fernqvist-Forbes E \& Wahren J 1995 Protein dynamics in whole body and in splanchnic and leg tissues in type I diabetic patients. Journal of Clinical Investigation 95 2926-2937. (doi:10.1172/JCI118000)

Nakagawa Y, Nagasawa M, Yamada S, Hara A, Mogami H, Nikolaev VO, Lohse MJ, Shigemura N, Ninomiya Y \& Kojima I 2009 Sweet taste receptor expressed in pancreatic $\beta$-cells activates the calcium and cyclic AMP signaling systems and stimulates insulin secretion. PLOS ONE 4 e5106. (doi:10.1371/journal.pone.0005106)

Nakagawa Y, Nagasawa M, Mogami H, Lohse M, Ninomiya Y \& Kojima I 2013 Multimodal function of the sweet taste receptor expressed in pancreatic $\beta$-cells: generation of diverse patterns of intracellular signals by sweet agonists. Endocrine Journal 60 1191-1206. (doi:10.1507/ endocrj.EJ13-0282)

Newgard CB 2012 Interplay between lipids and branched-chain amino acids in development of insulin resistance. Cell Metabolism 15 606-614. (doi:10.1016/j.cmet.2012.01.024)

Newgard CB, An J, Bain JR, Muehlbauer MJ, Stevens RD, Lien LF, Haqq AM, Shah SH, Arlotto M, Slentz CA et al. 2009 A branched-chain amino acidrelated metabolic signature that differentiates obese and lean humans and contributes to insulin resistance. Cell Metabolism 9 311-326. (doi:10.1016/j.cmet.2009.02.002)

Newsholme P \& Krause M 2012 Nutritional regulation of insulin secretion: implications for diabetes. Clinical Biochemist. Reviews 33 35-47.

Newsholme P, Bender K, Kiely A \& Brennan L 2007a Amino acid metabolism, insulin secretion and diabetes. Biochemical Society Transactions 35 1180-1186. (doi:10.1042/BST0351180)

Newsholme P, Keane D, Welters HJ \& Morgan NG 2007b Life and death decisions of the pancreatic $\beta$-cell: the role of fatty acids. Clinical Science 112 27-42. (doi:10.1042/CS20060115)

Newsholme P, Gaudel C \& McClenaghan NH 2010 Nutrient regulation of insulin secretion and $\beta$-cell functional integrity. Advances in Experimental Medicine and Biology 654 91-114.

Newsholme P, Abdulkader F, Rebelato E, Romanatto T, Pinheiro CH, Vitzel KF, Silva EP, Bazotte RB, Procopio J, Curi R et al. 2011 Amino acids and diabetes: implications for endocrine, metabolic and immune function. Frontiers in Bioscience 16 315-339. (doi:10.2741/3690)

Newsholme P, Gaudel C \& Krause M 2012a Mitochondria and diabetes. An intriguing pathogenetic role. Advances in Experimental Medicine and Biology 942 235-247. (doi:10.1007/978-94-007-2869-1_10)

Newsholme P, Rebelato E, Abdulkader F, Krause M, Carpinelli A \& Curi R $2012 b$ Reactive oxygen and nitrogen species generation, antioxidant defenses, and $\beta$-cell function: a critical role for amino acids. Journal of Endocrinology 214 11-20. (doi:10.1530/JOE-12-0072)

Nicastro H, da Luz CR, Chaves DF, Bechara LR, Voltarelli VA, Rogero MM \& Lancha AH Jr 2012 Does branched-chain amino acids supplementation modulate skeletal muscle remodeling through inflammation modulation? Possible mechanisms of action Journal of Nutrition and Metabolism 2012 136937. (doi:10.1155/2012/136937)

Nicklin P, Bergman P, Zhang B, Triantafellow E, Wang H, Nyfeler B, Yang H, Hild M, Kung C, Wilson C et al. 2009 Bidirectional transport of amino acids regulates mTOR and autophagy. Cell 136 521-534. (doi:10.1016/ j.cell.2008.11.044)

Nielsen K, Sorensen PG, Hynne F \& Busse HG 1998 Sustained oscillations in glycolysis: an experimental and theoretical study of chaotic and complex periodic behavior and of quenching of simple oscillations. Biophysical Chemistry 72 49-62. (doi:10.1016/S0301-4622(98)00122-7)

Nolan CJ \& Prentki M 2008 The islet $\beta$-cell: fuel responsive and vulnerable. Trends in Endocrinology and Metabolism 19 285-291. (doi:10.1016/j.tem. 2008.07.006)
Nolan CJ, Madiraju MS, Delghingaro-Augusto V, Peyot ML \& Prentki M $2006 a$ Fatty acid signaling in the $\beta$-cell and insulin secretion. Diabetes 55(Suppl 2) S16-S23. (doi:10.2337/db06-S003)

Nolan CJ, Leahy JL, Delghingaro-Augusto V, Moibi J, Soni K, Peyot ML, Fortier M, Guay C, Lamontagne J, Barbeau A et al. $2006 b \beta$ cell compensation for insulin resistance in Zucker fatty rats: increased lipolysis and fatty acid signalling. Diabetologia 49 2120-2130. (doi:10.1007/s00125-006-0305-5)

Oh DY, Talukdar S, Bae EJ, Imamura T, Morinaga H, Fan W, Li P, Lu WJ, Watkins SM \& Olefsky JM 2010 GPR120 is an omega-3 fatty acid receptor mediating potent anti-inflammatory and insulin-sensitizing effects. Cell 142 687-698. (doi:10.1016/j.cell.2010.07.041)

Ohanna M, Sobering AK, Lapointe T, Lorenzo L, Praud C, Petroulakis E, Sonenberg N, Kelly PA, Sotiropoulos A \& Pende M 2005 Atrophy of S6K1 $(-/-)$ skeletal muscle cells reveals distinct mTOR effectors for cell cycle and size control. Nature Cell Biology 7 286-294. (doi:10.1038/ncb1231)

Palacin M, Estevez R, Bertran J \& Zorzano A 1998 Molecular biology of mammalian plasma membrane amino acid transporters. Physiological Reviews 78 969-1054.

Pratt WB, Morishima Y, Peng HM \& Osawa Y 2010 Proposal for a role of the Hsp90/Hsp70-based chaperone machinery in making triage decisions when proteins undergo oxidative and toxic damage. Experimental Biology and Medicine 235 278-289. (doi:10.1258/ebm.2009.009250)

Remedi MS, Rocheleau JV, Tong A, Patton BL, McDaniel ML, Piston DW, Koster JC \& Nichols CG 2006 Hyperinsulinism in mice with heterozygous loss of K(ATP) channels. Diabetologia 49 2368-2378. (doi:10.1007/s00125-006-0367-4)

Roduit R, Nolan C, Alarcon C, Moore P, Barbeau A, Delghingaro-Augusto V, Przybykowski E, Morin J, Masse F, Massie B et al. 2004 A role for the malonyl-CoA/long-chain acyl-CoA pathway of lipid signaling in the regulation of insulin secretion in response to both fuel and nonfuel stimuli. Diabetes 53 1007-1019. (doi:10.2337/diabetes.53.4.1007)

Rommel C, Bodine SC, Clarke BA, Rossman R, Nunez L, Stitt TN, Yancopoulos GD \& Glass DJ 2001 Mediation of IGF-1-induced skeletal myotube hypertrophy by PI(3)K/Akt/mTOR and PI(3)K/Akt/GSK3 pathways. Nature Cell Biology 3 1009-1013. (doi:10.1038/ncb1101-1009)

Roos S, Lagerlof O, Wennergren M, Powell TL \& Jansson T 2009 Regulation of amino acid transporters by glucose and growth factors in cultured primary human trophoblast cells is mediated by mTOR signaling. American Journal of Physiology. Cell Physiology 297 C723-C731. (doi:10.1152/ajpcell.00191.2009)

Rorsman P \& Braun M 2013 Regulation of insulin secretion in human pancreatic islets. Annual Review of Physiology 75 155-179. (doi:10.1146/ annurev-physiol-030212-183754)

Ruderman N \& Prentki M 2004 AMP kinase and malonyl-CoA: targets for therapy of the metabolic syndrome. Nature Reviews. Drug Discovery 3 340-351. (doi:10.1038/nrd1344)

Russell ST, Rajani S, Dhadda RS \& Tisdale MJ 2009 Mechanism of induction of muscle protein loss by hyperglycaemia. Experimental Cell Research 315 16-25. (doi:10.1016/j.yexcr.2008.10.002)

Sabio G, Kennedy NJ, Cavanagh-Kyros J, Jung DY, Ko HJ, Ong H, Barrett T, Kim JK \& Davis RJ 2010 Role of muscle c-Jun NH2-terminal kinase 1 in obesity-induced insulin resistance. Molecular and Cellular Biology 30 106-115. (doi:10.1128/MCB.01162-09)

Salvucci M, Neufeld Z \& Newsholme P 2013 Mathematical model of metabolism and electrophysiology of amino acid and glucose stimulated insulin secretion: in vitro validation using a $\beta$-cell line. PLoS ONE 8 e52611. (doi:10.1371/journal.pone.0052611)

Sartorelli V \& Fulco M 2004 Molecular and cellular determinants of skeletal muscle atrophy and hypertrophy. Science's STKE 2004 re11.

Sato Y, Aizawa T, Komatsu M, Okada N \& Yamada T 1992 Dual functional role of membrane depolarization $/ \mathrm{Ca}^{2+}$ influx in rat pancreatic B-cell. Diabetes 41 438-443. (doi:10.2337/diab.41.4.438)

Sener A \& Malaisse WJ 1980 L-leucine and a nonmetabolized analogue activate pancreatic islet glutamate dehydrogenase. Nature $\mathbf{2 8 8}$ 187-189. (doi:10.1038/288187a0) 
Sener A, Best LC, Yates AP, Kadiata MM, Olivares E, Louchami K, Jijakli H, Ladriere L \& Malaisse WJ 2000 Stimulus-secretion coupling of arginineinduced insulin release: comparison between the cationic amino acid and its methyl ester. Endocrine 13 329-340. (doi:10.1385/ ENDO:13:3:329)

Shapiro H, Shachar S, Sekler I, Hershfinkel M \& Walker MD 2005 Role of GPR40 in fatty acid action on the $\beta$ cell line INS-1E. Biochemical and Biophysical Research Communications 335 97-9104. (doi:10.1016/j.bbrc. 2005.07.042)

Shulman GI, Rothman DL, Jue T, Stein P, DeFronzo RA \& Shulman RG 1990 Quantitation of muscle glycogen synthesis in normal subjects and subjects with non-insulin-dependent diabetes by $13 \mathrm{C}$ nuclear magnetic resonance spectroscopy. New England Journal of Medicine 322 223-228. (doi:10.1056/NEJM199001253220403)

Sugden MC \& Holness MJ 2011 The pyruvate carboxylase-pyruvate dehydrogenase axis in islet pyruvate metabolism: going round in circles? Islets 3 302-319. (doi:10.4161/isl.3.6.17806)

Taniguchi CM, Emanuelli B \& Kahn CR 2006 Critical nodes in signalling pathways: insights into insulin action. Nature Reviews. Molecular Cell Biology 7 85-96. (doi:10.1038/nrm1837)

Tateya S, Kim F \& Tamori Y 2013 Recent advances in obesity-induced inflammation and insulin resistance. Frontiers in Endocrinology 493. (doi:10.3389/fendo.2013.00093)

Tomita T, Masuzaki H, Iwakura H, Fujikura J, Noguchi M, Tanaka T, Ebihara K, Kawamura J, Komoto I, Kawaguchi Y et al. 2006 Expression of the gene for a membrane-bound fatty acid receptor in the pancreas and islet cell tumours in humans: evidence for GPR40 expression in pancreatic $\beta$ cells and implications for insulin secretion. Diabetologia 49 962-968. (doi:10.1007/s00125-006-0193-8)

Towler MC \& Hardie DG 2007 AMP-activated protein kinase in metabolic control and insulin signaling. Circulation Research 100 328-341. (doi:10.1161/01.RES.0000256090.42690.05)

Tremblay A \& Gilbert JA 2009 Milk products, insulin resistance syndrome and type 2 diabetes. Journal of the American College of Nutrition 28(Suppl 1) 91S-102S. (doi:10.1080/07315724.2009.10719809)

Turley S, Poirot L, Hattori M, Benoist C \& Mathis D 2003 Physiological $\beta$ cell death triggers priming of self-reactive T cells by dendritic cells in a type-1 diabetes model. Journal of Experimental Medicine 198 1527-1537. (doi:10.1084/jem.20030966)

Usher-Smith JA, Huang CLH \& Fraser JA 2009 Control of cell volume in skeletal muscle. Biological Reviews 84 143-159. (doi:10.1111/j.1469185X.2008.00066.X)

Vandanmagsar B, Youm YH, Ravussin A, Galgani JE, Stadler K, Mynatt RL, Ravussin E, Stephens JM \& Dixit VD 2011 The NLRP3 inflammasome instigates obesity-induced inflammation and insulin resistance. Nature Medicine 17 179-188. (doi:10.1038/nm.2279)

Vassiliou E, Gonzalez A, Garcia C, Tadros J, Chakraborty G \& Toney J 2009 Oleic acid and peanut oil high in oleic acid reverse the inhibitory effect of insulin production of the inflammatory cytokine TNF- $\alpha$ both in vitro and in vivo systems. Lipids in Health and Disease 8 25. (doi:10.1186/1476$511 \mathrm{X}-8-25)$

van der Velden JL, Langen RC, Kelders MC, Willems J, Wouters EF, JanssenHeininger YM \& Schols AM 2007 Myogenic differentiation during regrowth of atrophied skeletal muscle is associated with inactivation of GSK-3ß. American Journal of Physiology. Cell Physiology 292 C1636-C1644. (doi:10.1152/ajpcell.00504.2006)

Welsh N, Cnop M, Kharroubi I, Bugliani M, Lupi R, Marchetti P \& Eizirik DL 2005 Is there a role for locally produced interleukin- 1 in the deleterious effects of high glucose or the type 2 diabetes milieu to human pancreatic islets? Diabetes 54 3238-3244. (doi:10.2337/diabetes.54.11.3238)

Wen H, Gris D, Lei Y, Jha S, Zhang L, Huang MT, Brickey WJ \& Ting JP 2011 Fatty acid-induced NLRP3-ASC inflammasome activation interferes with insulin signaling. Nature Immunology 12 408-415. (doi:10.1038/ni.2022)

Westermark PO \& Lansner A 2003 A model of phosphofructokinase and glycolytic oscillations in the pancreatic $\beta$-cell. Biophysical Journal 85 126-139. (doi:10.1016/S0006-3495(03)74460-9)

White MF 2003 Insulin signaling in health and disease. Science 302 1710-1711. (doi:10.1126/science.1092952)

Whiting DR, Guariguata L, Weil C \& Shaw J 2011 IDF diabetes atlas: global estimates of the prevalence of diabetes for 2011 and 2030. Diabetes Research and Clinical Practice 94 311-321. (doi:10.1016/ j.diabres.2011.10.029)

Wierup N, Sundler F \& Heller RS 2014 The islet ghrelin cell. Journal of Molecular Endocrinology 52 R35-R49. (doi:10.1530/JME-13-0122)

Wijekoon EP, Skinner C, Brosnan ME \& Brosnan JT 2004 Amino acid metabolism in the Zucker diabetic fatty rat: effects of insulin resistance and of type 2 diabetes. Canadian Journal of Physiology and Pharmacology 82 506-514. (doi:10.1139/y04-067)

$\mathrm{Xu}$ J, Han J, Long YS, Epstein PN \& Liu YQ 2008 The role of pyruvate carboxylase in insulin secretion and proliferation in rat pancreatic $\beta$ cells. Diabetologia 51 2022-2030. (doi:10.1007/s00125-008-1130-9)

Yang J, Wong RK, Park M, Wu J, Cook JR, York DA, Deng S, Markmann J, Naji A, Wolf BA et al. 2006 Leucine regulation of glucokinase and ATP synthase sensitizes glucose-induced insulin secretion in pancreatic $\beta$-cells. Diabetes 55 193-201. (doi:10.2337/diabetes.55.01.06.db05-0938)

Yano M, Inoue M, Maehata E, Shiba T, Yamakado M, Hirabayashi Y, Taniyama M \& Suzuki S 2004 Increased electronegative charge of serum low-density lipoprotein in patients with diabetes mellitus. Clinica Chimica Acta 340 93-98. (doi:10.1016/j.cccn.2003.09.020)

Zhang Y, Proenca R, Maffei M, Barone M, Leopold L \& Friedman JM 1994 Positional cloning of the mouse obese gene and its human homologue. Nature 372 425-432. (doi:10.1038/372425a0)

Zhang X, Xu A, Chung SK, Cresser JH, Sweeney G, Wong RL, Lin A \& Lam KS 2011 Selective inactivation of c-Jun NH2-terminal kinase in adipose tissue protects against diet-induced obesity and improves insulin sensitivity in both liver and skeletal muscle in mice. Diabetes 60 486-495. (doi:10.2337/db10-0650)

Received in final form 5 March 2014

Accepted 13 March 2014

Accepted Preprint published online 25 March 2014 http://joe.endocrinology-journals.org DOI: 10.1530/JOE-13-0616
() 2014 Society for Endocrinology Printed in Great Britain
Published by Bioscientifica Ltd. 